\title{
HUBUNGAN PERSEPSI MASYARAKAT TENTANG KUALITAS PELAYANAN POSYANDU LANSIA TERHADAP KUNJUNGAN POSYANDU LANSIA DI PUSKESMASX KOTA KEDIRI
}

\author{
Gita Sekar Prihanti ${ }^{1}$, Genio Rachmadana ${ }^{1}$, Irvia Widya Ramadani ${ }^{1}$ \\ Fakultas Kedokteran Universitas Muhammadiyah Malang. \\ J1. Bendungan Sutami No.188A Malang
}

Email : gitasekarprihanti@gmail.com

\begin{abstract}
ABSTRAK
Latar Belakang : Pembangunan kesehatan yang merupakan salahsatu program prioritas dalam mewujudkan agenda pembangunan nasional mempunyai arah kebijakan yaitu meningkatnya akses masyarakat terhadap pelayanan kesehatan masyarakat yang ditandai dengan meningkatnya angka harapan hidup, meningkatkankesejahteraanhidup, dan meningkatkan kesehatan masyarakat terutama, masyarakat lansia. Metode : Desain penelitian cross sectional. Pengambilan sampel dengan teknik total sampling. Jumlah sampel 81 orang. Pelaksanaan penelitian dilakukan di Bulan Mei 2016. Hasil Penelitian : Berdasarkan hasil kuesioner didapatkan laki-laki 13 orang (16\%) dan wanita 68 orang (84\%). Dari penelitian di dapatkan dimensi kualitas pelayanan empathy mempunyai pengaruh paling besar dengan rata-rata terbanyak sebesar 3.96. Hasil analisis multivariate regresi logistik didapatkan hubungan yang signifikan antara dimensi kualitas pelayanan empathy terhadap kunjungan posyandu lansia yaitu dengan ( $\mathrm{p}=0,022)$. Kesimpulan : Terdapat hubungan antara persepsi masyarakat tentang kualitas pelayanan Posyandu Lansia terhadap kunjungan lansia lansia di Puskesmas X Kota Kediri.
\end{abstract}

Kata Kunci: persepsimasyarakat, kualitaspelayanan, posyandulansia, PuskesmasX.

\begin{abstract}
Background:Health development was a priority program to realize national development agenda. The direction of policy was to improve the access of community to healthcare. Such improvement was marked by the improved rates of life expectancy, life welfare, and community welfare. Community member who was the center of attention in this research was elders. Method:Research design was cross sectional. Sampling technique was total sampling and involved81 respondents. Result of Research:As shown by questionnaire, men were 13 respondents (16\%) and women were 68 respondents (84\%). A dimension of quality service, empathy,had the biggest effect, with the greatest mean rate at 3.96. Result of logistic regression multivariate analysis indicated that there was a significant relationship between empathy and Integrated Service Post for Elders $(\mathrm{p}=0.022$ ). Conclusion:There was relationship between community perception about service quality at Integrated Service Post for Elders and the visit to this Service Post in Community Health Service, Kediri City.
\end{abstract}

Keywords : community perception, service quality, Integrated Service Post for Elders, Community Health Service. 


\section{PENDAHULUAN}

Pembangunan kesehatan yang merupakan salah satu program prioritas dalam mewujudkan agenda pembangunan nasional $\mathrm{m}$ empunyai arah kebijakan yaitu meningkatnya ak ses masyarakat terhadap pelayanan kesehatan masyarakat yang ditandai dengan meningkatnya angka harapan hidup, meningkatkan kesejahteraan hidup, dan meningkatkan kesehatan masyarakat terutama, masyarakat lansia. Sesuai dengan deklarasi Alma Ata tahun 1978 salah satu pendekatan dalam p embangunan kesehatan adalah pendekatan kesehatan masyarakat melalui partisipasi masyarakat (Budi, 2011)

Menurut Undang-Undang Republik Indonesia Nomor 13 tahun 1998 tentang Kesejahteraan Lanjut Usia, yang dimaksud dengan lanjut usia (lansia) adalah seseorang yang telah mencapai usia 60 tahun keatas (KEMENKES RI, 2014). Saat ini diseluruh dunia jumlah orang lanjutusia diperkirakan ada 500 juta dengan usia rata-rata 60 tahun dan diperkirakan pada tahun 2025 akan menyapai 1,2 milyar (Nugroho, 2010). Jumlah lansia di Indonesia mencapai 20,24 juta jiwa, setara dengan 8,03\% dari seluruh penduduk Indonesia tahun 2014 (BAPPENAS, 2015).

Posyandu merupa kan salah satu bentuk Upaya Kesehatan Bersumberdaya Masyarakat (UKBM) yang dikelola dan diselenggarakan dari, oleh, untuk dan bersama masyarakat dalam penyelenggaraan pembangunan kesehatan, guna memberdayakan $\mathrm{m}$ asyarakat dan memberikan kemudahan kepada $m$ asyarakat dalam memperoleh pelayanan kesehatan dasar untuk mempercepat penurunan angka kematian ibu dan bayi (KEMENKES RI, 2014).

Berdasarkanhasilrisetkesehatandasarpadatahun 2007, jumlah Posyandu semakin meningkat tetapi pemanfaatan dan kualitas perlu ditingkatkan. Padatahun 2007 sebanyak 27,3\% RumahTangga (RT) yang memanfaatkan Posyandu, sebanyak 10\% membutuhkan tetapi tidak memanfaatkan Posyandu, dan sebanyak $62,5 \%$ tidak membutuhkan dengan alasan karena pelayanan Posyandu tidak lengkap 49,6\%, akses Posyandu jauh sebanyak 26\%, dan tidak ada Posyandu sebanyak 24\% (KEMENKES, 2011).

\section{METODE}

Penelitian ini dilaksanakan di Posyandu lansia, Puskesmas X Kota Kediri.Penelitian inimerupakan penelitian cross-sectional dengan metode total sampling, yang dilakukan pada bulan Mei 2016. Kriteria inklusi adalah lansia terdaftar menjadi anggota di posyandu lansia., lansia bisa berkomunikasi dengan baik, lansia yang bersedia mengisi angket dalam penelitian, respon den berumur diatas 60 tahun dan telah memiliki Kartu Tanda Penduduk.

Subjek penelitian adalah lansia yang berkunjung di posyandu lansia di bulan Mei 2015 - Mei 2016.Untuk responden sendiri dilihat dari data yang terdapat di Posyandu. Lalu kemudian dari nama-nama yang terdata tersebut didatangi satu persatu untuk mengisi kuisioner.

Responden diberikan kuisioner perseps i masyarakat tentang kualitas pelayanan posyandu. Kusioner ini digunakan untuk menge tahui persepsi masyarakat tentang kualitas posyandu lansia.

Kuesioner terdiri dari 25 pertanyaan dan terbagi menjadi lima dimensi, yaitu Tangibles, Reliability, Responsiveness, Assurance, Empathy. Dan masing masing dimensi terdapat lima pertanyaan dengan nilai $(\mathrm{SB}=5, \mathrm{~B}=4, \mathrm{~S}=3, \mathrm{~TB}=2, \mathrm{STB}=1)$. Kemudian tiap masing-masing dimensi dijumlahkan dandirata-rata. Kualitas posyandu baik, jika nilai diatas rata-rata.

Hasil penelitian akan dilakukan uji dengan menggunakan analisis bivariat (uji fisher) dan multivariat (regresi logistik) menggunakan SPSS 21 for windows.

\section{HASIL}

Dari hasil penelitian didapatkan jumlah responden 81 orang.

Tabel5.1 Distribusi Kunjungan Berdasarkan Jenis Kelamin

\begin{tabular}{|l|c|c|}
\hline JenisKelamin & $\mathbf{N}$ & $\mathbf{\%}$ \\
\hline Laki-laki & 13 & 16 \\
\hline Perempuan & 68 & 84 \\
\hline Total & 81 & 100,0 \\
\hline
\end{tabular}


Dari 81 responden sebagian besar merupakan perempuan sebanyak 68 orang (84\%), sedangkan responden laki-laki sebanyak 13 orang (16\%).

Tabel 5.2 Distribusi Kunjungan Berdasarkan Usia

\begin{tabular}{|c|c|c|}
\hline Usia & $\mathbf{N}$ & $\mathbf{\%}$ \\
\hline $\mathbf{6 0 - 6 9}$ th & 56 & 69 \\
\hline $\mathbf{7 0 - 7 9}$ th & 20 & 25 \\
\hline $\mathbf{= 8 0}$ th & 5 & 6 \\
\hline Total & 81 & 100,0 \\
\hline
\end{tabular}

Dari 81 responden sebagian besar berusia 60 tahun sebanyak 18 orang $(22,2 \%)$, sedangkan responden yang paling sedikit berusia $71,80,85$, dan 86 tahun sebanyak 1 orang $(1,2 \%)$.

Tabel 5.3 Distribusi Posyandu Berdasarkan Pembagian Wilayah Kerja Posyandu

\begin{tabular}{|l|c|c|}
\hline Posyandu & $\mathbf{N}$ & $\mathbf{\%}$ \\
\hline Taman Mekarsari 1 & 10 & 12,3 \\
\hline Taman Mekarsari 2 & 25 & 30,9 \\
\hline Taman Mekarsari 3 & 18 & 22,2 \\
\hline Taman Mekarsari 4 & 12 & 14,8 \\
\hline Taman Mekarsari 5 & 16 & 19,8 \\
\hline Total & 81 & 100,0 \\
\hline
\end{tabular}

Berdasarkan data di atas, dari 81 responden sebagian besar berada di Posyandu Taman Mekarsari 2 sebanyak 25 orang $(30,9 \%)$, sedangkanresponden yang paling sedikit di Posyandu Taman Mekarsari 1sebanyak10 orang (12,3\%).

Tabel 5.4 Distribusi Kunjungan Lansia

\begin{tabular}{|l|c|c|}
\hline & $\mathrm{N}$ & $\%$ \\
\hline Aktif & 45 & 55,6 \\
\hline KurangAk tif & 36 & 44,4 \\
\hline Total & 81 & 100,0 \\
\hline
\end{tabular}

Berdasarkan data di atas, dari 81 responden sebagian besar aktif sebanyak 45 orang (55.6\%), sedangkan responden yang kurang aktif sebanyak 36 orang $(44.4 \%)$.

Tabel 5.5 Distribusi KunjunganBerdasarkan Tingkat Pendidikan

\begin{tabular}{|l|c|c|}
\hline Tingkat Pendidikan & N & $\%$ \\
\hline TidakSekolah & 33 & 41 \\
\hline SD & 31 & 38 \\
\hline SMP & 13 & 16 \\
\hline SMA & 4 & 5 \\
\hline Total & 81 & 100,0 \\
\hline
\end{tabular}

Berdasarkan data di atas, dari 81 responden berdasa rkan tingkat pendidikan sebagian besar tidak sekolah sebanyak 33 orang (41\%), sedangkan responden yang paling sedikit berpendidikan SMA sebanyak 4 orang $(5 \%)$.

Tabel 5.6 Distribusi Kualitas Pelayanan dengan Kunjungan posyandu

\begin{tabular}{|l|c|c|c|}
\hline \multirow{2}{*}{$\begin{array}{l}\text { Persepsi } \\
\text { Kualitas }\end{array}$} & \multicolumn{2}{|c|}{ Kunjungan } & \multirow{2}{*}{$\%$} \\
\cline { 2 - 3 } & Aktif & Kurangaktif & \\
\hline Baik & $40(49.4 \%)$ & $7(8.6 \%)$ & 58.0 \\
\hline Kurang & $3(3.7 \%)$ & $31(38.3 \%)$ & 42.0 \\
\hline Total & $43(53.1 \%)$ & $38(46.9 \%)$ & 100,0 \\
\hline
\end{tabular}

Berdasarkan data hasil penelitian yang terbanyak didapatkan responden dengan kualitas pelayanan baik dan kunjungan posyandu aktif sebanyak 40 orang, sedangkan responden dengan kualitas pelaya nan kurang dan kunjungan posyandu kurang aktif sebanyak 31 orang. 
Tabel 5.7 DistribusiNilai Rata-Rata tiapPosyanduLansia

\begin{tabular}{|l|c|c|c|c|c|c|}
\hline \multirow{2}{*}{ Posyandu } & \multicolumn{5}{|c|}{ PersepsiKualitasPelayananPosyandu } & \multirow{2}{*}{ Mean } \\
\cline { 2 - 7 } & Tangibles & Reliability & Responsiveness & Asurance & Empathy & \\
\hline Taman Mekarsari 1 & 3,94 & 3,96 & 4,08 & 3,92 & 4,00 & 3,97 \\
\hline Taman Mekarsari 2 & 3,90 & 3,77 & 3,76 & 3,82 & 3,94 & 3,81 \\
\hline Taman Mekarsari 3 & 3,97 & 3,87 & 3,90 & 3,83 & 4,02 & 3,89 \\
\hline Taman Mekarsari 4 & 3,73 & 3,9 & 3,75 & 3,65 & 3,8 & 3,76 \\
\hline Taman Mekarsari 5 & 3,94 & 3,96 & 3,81 & 3,81 & 4,01 & 3,89 \\
\hline KelurahanTamanan & 3,90 & 3,89 & 3,86 & 3,81 & 3,95 & 3,88 \\
\hline
\end{tabular}

Tabel 5.9 Hasil analisis deskriptif

\begin{tabular}{|l|c|c|c|c|c|c|}
\hline \multicolumn{1}{|c|}{ Variabel } & $\mathrm{N}$ & Min & Max & Sum & Mean & Std. Deviation \\
\hline Usia & 81 & 60 & 88 & 5417 & 66.88 & 6.729 \\
\hline Jeni Kelamin & 81 & 1 & 2 & 149 & 1.84 & .0369 \\
\hline Jumlah Kunjungan & 81 & 2 & 12 & 603 & 7.44 & 2.269 \\
\hline Tangibles & 81 & 2.00 & 5.00 & 316.00 & 3.9012 & .37964 \\
\hline Reliability & 81 & 3.00 & 5.00 & 313.60 & 3.8716 & .37856 \\
\hline Responsiveness & 81 & 2.20 & 5.00 & 311.00 & 3.8395 & .42944 \\
\hline Assurance & 81 & 2.00 & 4.40 & 308.40 & 3.8074 & .41526 \\
\hline Empathy & 81 & 3.00 & 5.00 & 320.60 & 3.9580 & .29617 \\
\hline
\end{tabular}

Tabel 5.10 Analisis Bivariat Antara Variabel Dependen dan Variabel Independen

\begin{tabular}{|l|c|c|}
\hline \multicolumn{1}{|c|}{ Variabel } & $\mathrm{P}$ & \multicolumn{1}{c|}{ Keterangan } \\
\hline Tangibles & .000 & Bermakna $(\mathrm{p}<0,05)$ \\
\hline Reliability & .000 & Bermakna $(\mathrm{p}<0,05)$ \\
\hline Responsiveness & .006 & Bermakna $(\mathrm{p}<0,05)$ \\
\hline Assurance & .000 & Bermakna $(\mathrm{p}<0,05)$ \\
\hline Empathy & .012 & Bermakna $(\mathrm{p}<0,05)$ \\
\hline
\end{tabular}

Tabel 5.12 Regresi Logistik

\begin{tabular}{|l|c|c|c|c|c|}
\hline \multirow{2}{*}{ Variabel } & \multirow{2}{*}{$\mathrm{B}$} & \multirow{2}{*}{ Sig } & \multirow{2}{*}{$\operatorname{Exp}(\mathrm{B})$} & \multicolumn{2}{c|}{ CI } \\
\cline { 5 - 6 } & & & & Lower & Upper \\
\hline Tangibles & 1.088 & .153 & .337 & .076 & 1.499 \\
\hline Reliability & .772 & .219 & .462 & .135 & 1.584 \\
\hline Responsiveness & 1.280 & .118 & .278 & .056 & 1.383 \\
\hline Assurance & .748 & .311 & .473 & .112 & 2.009 \\
\hline Empathy & .1 .453 & .022 & 4.276 & 1.229 & 14.879 \\
\hline
\end{tabular}

Berdasarkan tabel 5.7 dari persepsi kualitas pelayanan posyandu lansia kelurahan memiliki ratarata 3.88. dapat disimpulkan terdapat 3 posyandu lansia yang memiliki kualitas pelayanan baik menurut masyarakat yaitu posyandu lansia taman mekarsari 1, 3 dan 5. Sedangkan posyandu taman mekarsari 2 dan 4 memiliki kualitas pelayanan yang kurang. Dimensi pelayanan yang memiliki nilai nilai paling tinggi adalah empathy dan dimensi pelayanan yang memiliki nilai paling rendah adalah assurance.

Berdasarkan tabel 5.10 di atas diketahui pada analisis bivariat menunjukkan bahwa terdapat lima variabel mempunyai pengaruh signifikan terhadap kunjungan posyandu lansia, yaitu Tangibles ( $\mathrm{p}=$ $0,000)$, Reliability ( $p=0,000)$, Responsiveness ( $p=$ $0,006)$, Assurance $(p=0,000)$, Empathy $(p=0,012)$. 
Tabel 5.11 Nagelkerke R Square

\begin{tabular}{|c|c|c|}
\hline $\begin{array}{c}-2 \log \\
\text { likelihood }\end{array}$ & $\begin{array}{c}\text { Cox \& Snell } \\
\text { R Square }\end{array}$ & $\begin{array}{c}\text { Nagelkerke } \\
\text { R Square }\end{array}$ \\
\hline 89.036 & .247 & .329 \\
\hline
\end{tabular}

Berdasarkan tabel 5.11 nilai Nagelkerke $R$ square yaitu 0,329 (32,9\%), maka menunjukkan bahwa sebesar 32,9\% kunjungan posyandu dapat dijelaskan enam variabel yang berhubungan tersebut, sedangkan 67,1\% kunjungan posyandu dapat dijelaskan oleh variabel lain yang belum diteliti dalam penelitian ini seperti pengaruh dukungan keluarga.

Berdasarkan tabel 5.12 uji regresi logistik didapatkan kualitas pelayanan $(\mathrm{p}<0.05)$ menurut persepsi masyarakat memiliki hubungan terhadap kunjungan posyandu lansia di wilayah kerja puskesmas X kota Kediri.

$$
\begin{aligned}
\mathrm{y} & =1.876+(\text { Empathy }) \mathrm{x} 1 \\
& =1.876+1.453 \\
& =3.329
\end{aligned}
$$

\section{PEMBAHASAN}

Dari hasil penelitian didapatkan jumlah responden 81 orang menunjukkan sebagian besar adalah kunjungan lansia berjenis kelamin perempuan, dan sebagian kecil adalah kunjungan yang berjenis kelamin laki-laki. Berdasarkan data yang telah diteliti, berdasarkan jenis kelamin di 5 Posyandu Lansia diperoleh lansia perempuan cenderung mempunyai perilaku aktif untuk mengikuti Posyandu lansia, sebaliknya bagi lansia laki-laki mempunyai perilaku kurang aktif. Hal ini sesuai dengan penelitian Rosyid dkk (2009) yang mengatakan perempuan lebih tekun dalam menghadapi tindakan terutama mengikuti Posyandu lansia. Laki-laki tentunya cepat bosan jika dilihat dari segi psikologis jika mengikuti Posyandu lansia, jadi kesimpulannya untuk meningkatkan perilaku lansia untuk berkunjung ke Posyandu lansia harus melalui promosi kesehatan dan penyuluhan. Hal ini juga sesuai dengan penelitian yang dilakukan oleh Hardywinoto dan Setiabudhi (2005) mengenai jumlah penduduk lansia di Indonesia, yang mengatakan bahwa jumlah penduduk lansia perempuan pada umumnya lebih banyak di bandingkan dengan lansia laki-laki.

Dari hasil penelitian terhadap 81 lansia didapatkan lansia yang berkunjung ke Posyandu Lansia sebagian besar adalah Tidak Sekolah, dan sebagian kecil adalah Sekolah Menengah Atas. Hal ini berarti tidak terdapat pengaruh yang berarti antara tingkat pendidikan terhadap kunjungan lansia ke posyandu. Pendidikan adalah suatu usaha untuk mengembangkan kepribadian dan kemampuan di dalam dan di luar sekolah dan berlangsung seumur hidup. Pendidikan mempengaruhi proses belajar, makin tinggi pendidikan seseorang makin mudah orang tersebut untuk menerima informasi. Dengan pendidikan tinggi maka seseorang akan cenderung untuk mendapatkan informasi, baik dari orang lain maupun dari media masa, semakin banyak informasi yang masuk semakin banyak pula pengetahuan yang didapat tentang kesehatan. Pendapat ini sangatlah bertentangan dengan hasil penelitian Ahmad, Hasanuddin dan Djewarut (2013), didapatkan rata - rata pendidikan responden adalah tamat SD. Disini Ahmad, Hasanuddin dan Djewarut (2013) berasumsi bahwa pengetahuan baik yang dimiliki responden bukan karena dipengaruhi oleh pendidikan responden, tetapi karena responden sudah berusia tua dan memiliki banyak pengetahuan, melalui pengalaman atau informasi dari orang lain.

Hal ini didukung oleh pendapat yang dikemukakan oleh Notoatmodjo (2007) bahwa selain pendidikan faktor lain yang mempengaruhi pengetahuan seseorang adalah umur dan pengalaman. Jones \& Beck, 1996 dalam Notoatmodjo (2007) mengatakan pengalaman belajar dalam bekerja yang dikembangkan memberikan pengetahuan dan ketrampilan profesional serta pengalaman belajar selama bekerja akan dapat mengembangkan kemampuan mengambil keputusan yang merupakan manifestasi dari keterpaduan menalar secara ilmiah dan etik yang bertolak dari masalah nyata dalam bidang keperawatan Semakin tua semakin bijaksana, semakin banyak informasi yang dijumpai dan semakin banyak hal yang dikerjakan sehingga menambah pengetahuannya.

Menurut Notoatmodjo (2007) konsep dasar pendidikan adalah suatu proses belajar yang berarti dalam pendidikan itu terjadi proses pertumbuhan, perkembangan atau perubahan ke arah yang lebih dewasa, lebih baik dan lebih matang pada diri individu, kelompok dan masyarakat. Kegiatan atau proses belajar apabila didalamnya terjadi perubahan dari tidak tahu menjadi tahu dari tidak mau mengerjakan menjadi mau mengerjakan sesuatu, namun demikian tidak semua 
perubahan itu terjadi karena belajar saja, tetapi juga karena proses kematangan dari perkembangan dirinya. Tidak adanya pengaruh tingkat pendidikan terhadap kunjungan lansia ke posyandu lansia tersebut mungkin saja terjadi. Karena pendidikan pada dasarnya tidak hanya dapat diperoleh dari bangku sekolah (formal) tetapi juga di lingkungan keluarga, masyarakat, dan dari media lainnya (majalah, berita, dll). Dari hasil penelitian terhadap 81 lansia pada tabel 5.2 distribusi kunjungan posyandu lansia berdasarkan usia, menunjukan bahwa lansia yang berumur 60-69 tahun mempunyai tingkat kunjungan ke posyandu yang lebih aktif. Berdasarkan data BAPPENAS tahun 2014 Jawa Timur menduduki peringkat ketiga dengan proporsi lansia terbesar yakni $10.96 \%$ dari seluruh Indonesia dibawah Jawa Tengah (11.11\%) dan DI. Yogyakarta (10.05\%). Sedangkan menurut usia, jumlah penduduk lansia terbanyak usia 60-69 tahun (60.93\%) dan proporsi lansia jenis kelamin perempuan pada tahun 2014 lebih tinggi 1.1\% dibanding proporsi lansia lakilaki. Sedangkan menurut Hardywinoto dan Setiabudhi (2005) umur mempunyai pengaruh terhadap tingkat pengetahuan dan kemandirian lansia dengan kriteria semakin lanjut usia seseorang maka akan semakin tinggi pengetahuan dan semakin rendah pula kemungkinan tingkat kemandirian lansia. Hal ini erat kaitannya dengan berbagai faktor pada lansia itu sendiri baik itu pengalaman, proses penuaan ataupun status kesehatannya dalam melakukan aktivitas fisiknya sehari-hari.

Secara keseluruhan berdasar kan kelima indikator sebagai dimensi pen gukuran kualitas pelayanan kesehatan Posyandu Lansia di Puskesmas X kota Kediri didapatkan hasil skor kualitas adalah 3.89. Dari kelima Posyandu Lansia di Puskesmas X didapatkan nilai rata-rata sebesar 4.02 pada Posyandu Lansia 1; nilai rata-rata sebesar 3.84 pada Posyandu Lansia 2; nilai rata-rata sebesar 3.92 pada Posyandu Lansia 3; nilai rata-rata sebesar 3.77 pada Posyandu Lansia 4; nilai rata-rata sebesar 3.91 pada Posyandu Lansia 5. Berdasarkan nilai rata-rata tersebut terdapat tiga Posyandu Lansia yang memilikinilai rata-rata diatas 3.88. Data tersebut berarti Posyandu Lansia 1, Posyandu Lansia 3, dan Posyandu Lansia 5 memiliki kualitas pelayanan yang baik.

Diurutkan menurut dimensi kualitas pelayanan, maka dimensi empathy mempunyai ratarata skor 3.96; tangibles mempunyai rata-rata skor 3.90; reliability mempunyai rata-rata skor 3.87; responsivennessmempunyai rata-rata skor 3.84; assurance mempunyai rata-rata skor paling rendah yaitu 3.81. Berdasarkan hasil tersebut, maka secara keseluruhan dapat disimpulkan bahwa dimensidimensi penting yang perlu mendapat perhatian guna peningkatan dan perbaikan lebih lanjut adalah assurance, dimana dimensi tersebut meliputi kemampuan, kesopanan, kepercayaan dan bebas dari mal praktek (Santoso, 2010). Hal ini sesuai dengan penelitian Cho et al., (2004) dimana dimensi yang paling penting pada grup dengan kunjungan posyandu lansia lebih dari 6 kali terhadap kepuasan pasien adalah perhatian dari tenaga medis.

Menurut Cho et al., (2004) kepuasan pasien merupakan hal yang penting karena kedua hal tersebut mengarah ketingginya kunjungan posyandu lansia kedatangan dan kepatuhan pasien terhadap saran petugas kesehatan. Sesuai dengan data kunjungan posyandu lansia dari kelima Posyandu Lansia di Puskesmas X didapatkan bahwa terdapat peningkatan kunjungan posyandu la nsia pada Posyandu Lansia dengan kualitas pelayanan yang baik.

\section{REFERENS}

Ahmad, Hasanuddin, Djewarut. 2013. Faktor yang Memnengaruhi Iansia dalam Mencanai di

Sudiang Raya Makassar.

BAPPF,NAS (Badan Pusat Statistik). 2015. Statistik

Statistik.

Budi IS, 2011. Manajemen Partisipatif; sebuah pen dekatan dalam meniokatkan neran serta kader desa. Jurnal Ilmu Kesehatan Masyarakat.

Cho WH, Lee H, Kim C, et al. 2004. The Impact of Visit Frequency on the Relationship hetween Service Ouality and Outnatient

Services Research 39:1. pp: 13-33.

Hardvwinoto. 2005. Panduan gerontolooi tiniauan dari

utama.

Kementrian Kesehatan Renublik Indonesia. 2011

Jakarta. 
Kementrian Kesehatan Renublik Indonesia. 2014.

dan Informasi. Jakarta: Infodatin.

dan aplikasi. Jakarta: Rineka Cipta.

Nugroho HA, Samiasih A, Sulistiyaningsih S, 2010. Pengetahuan Kader Tentang Proses Menua Denoan Keaktifan Kader nada Pelaksanaan

Kecamatan Tembelang Semarang

Rosyid NF, Uliyah M, Hasanah U, dkk. 2009. Faktor-Faktor yang Mempengaruhi Kuniunoan Tansia ke Posvandu Tansia di Kecamatan Semampir Surabaya.

Santoso. 2010. Persepsi Masyarakat terhadap Kualitas Pelavanan Kesehatan di Puskesmas

dan Biostatistika. 